\title{
Sujeito e o mundo: a aplicação das geotecnologias no ensino de Geografia como perspectiva da integralidade
}

\author{
Subject and the world: the application of geotechnologies in teaching \\ Geography as perspective or integrality
}

\author{
Isabel Cristina Bohn Vieira'(i), Eduardo Augusto Werneck Ribeiro"(i) \\ ' IFC - Instituto Federal Catarinense, Blumenau, SC, Brasil \\ "IFC - Instituto Federal Catarinense, Blumenau, SC, Brasil
}

\section{RESUMO}

Este artigo apresenta uma proposta de uma sequência didática (SD) com o tema recursos hídricos, exercitando a aplicação de geotecnologias no ensino de geografia para a educação básica. A proposta descreve um modelo de roteiro Sujeito e o Mundo, configurando um arcabouço atrativo e didático para o desenvolvimento de projetos de ensino, sob a perspectiva colaborativa, participativa entre educandos e educadores. Esta aplicação propicia aos envolvidos a educação cientifica onde se trabalha fundamentação dos conceitos (a hipótese, o raciocínio metodológico e os testes que a hipótese gera) através de atividades didáticas práticas e tecnológicas na geografia, além de encorajá-los a propor soluções de problemas ambientais e sociais vigentes, em pleno exercício da cidadania. Esta proposta de construção do conhecimento pode contribuir no processo de ensino e aprendizagem na medida que o conteúdo teórico da disciplina é contextualizado, materializado e discutido pelo experimento. Com os resultados pode-se discutir a plausibilidade das provas que a teoria apresenta, reforçando a importância de se inter-relacionar conceitos, de se fazer uma boa pergunta e buscar respostas com métodos e recursos adequados, assim, propiciando o aprendizado de forma integral.

Palavras-chave: Ciência Geográfica; Geotecnologias; Integralidade; Roteiro

\section{ABSTRACT}

This article presents a proposal for a didactic sequence (SD) with the theme of water resources, exercising the application of geotechnologies in the teaching of geography for basic education. The proposal describes a model of the Subject and the World script, setting up an attractive and didactic framework for the development of teaching projects, from a collaborative, participatory perspective between students and educators. This application provides those involved with scientific education where they work on the foundation of concepts (the hypothesis, methodological reasoning and the tests that the hypothesis generates) through practical and technological didactic activities in geography, in addition to encouraging them to propose solutions to environmental problems. current social rights, in full exercise of citizenship. This proposal for the construction of knowledge can contribute to the teaching and learning process as the theoretical content of the discipline 
is contextualized, materialized and discussed by the experiment. With the results, it is possible to discuss the plausibility of the evidence presented by the theory, reinforcing the importance of interrelating concepts, of asking a good question and seeking answers with appropriate methods and resources, thus providing comprehensive learning.

Keywords: Geographic Science; Geotechnologies; Integrality; Script

\section{INTRODUÇÃO}

Na contemporaneidade, as evidências que a sociedade experiencia uma crise ambiental é cada vez mais peremptório. "A expansão das áreas agrícolas, o aumento dos aglomerados urbanos, a exploração dos recursos naturais, são exemplos de ações antrópicas que provocam danosas alterações no ambiente" (VIEIRA, 2019, p.26). Estas ações, associadas ao desenvolvimento contínuo e mal planejado, geram impactos ambientais e socioeconômicos em diversas regiões do país.

Santos et al. (2019), afirma:

Um dos grandes desafios do homem, no que diz respeito à conservação ambiental, tem sido reunir esforços e recursos para a preservação e recuperação de áreas, consideradas estratégicas para a manutenção e conservação dos recursos naturais, das quais vários ecossistemas são dependentes (SANTOS et al., 2019, p.190).

Para minimizar essa crise ambiental não basta apenas iniciativas empresariais ou governamentais, é necessária a participação de todos os cidadãos, cientificamente informados acerca das consequências que a degradação do ambiente pode acarretar sobre sua própria vida e na vida de seus familiares. Conforme Witter (2007), o uso inadequado e ou a ausência de uso do conhecimento científico é também uma fonte de problemas que podem pôr em risco o próprio homem, ou até mesmo o planeta como todo.

Partindo desse pressuposto, reconhece-se a ciência como um poderoso recurso na construção do conhecimento, neste sentido, tanto a escola e seus atores (alunos, professores) podem inferir o conhecimento científico em sua práxis diária, concebendose como sujeito integrante do mundo. Para isto é necessário a apropriação do conhecimento científico, pois são a base para a fundamentação do que segundo Vygotsky chama de zona de desenvolvimento proximal, onde funções mentais como: 
memória voluntária, atenção seletiva e pensamento lógico são propícios para serem desenvolvidos na escola (VYGOTSKY, 1988). Assim, este espaço educacional proporcionará a interação, tanto das pessoas (o que também desenvolverá o conceito de zona de desenvolvimento potencial) como e com os processos que materializaram o espaço geográfico em que estão situados.

O conhecimento científico somente possibilitará que as reivindicações e soluções ecologicamente se tornem viáveis, se o educando se reconhecer com agente que compreende o meio e proativo a modificá-lo. É neste sentido que o papel da educação científica deve trilhar, apoiar estratégias didáticas que fomentem diálogos que: estimulem a construção de hipóteses; ofereça instrumentos metodológicos que possam testar (negando-a ou confirmando-a) a tese levantada e por fim, que permitam defender o seu ponto de vista por conta dos resultados. Todos estes elementos reforçarão o papel do conhecimento nas formulações de pessoas críticas, embasadas de conhecimento científico, o que não se permitirão ser convencidas passivam por uma outra pessoa.

Tendo isto posto, o objetivo desse artigo é contribuir para que acadêmicos e profissionais da educação possam fundamentar a cientificação de conceitos através de atividades didáticas práticas e tecnológicas na Área de Ciências Humanas - Ciência Geográfica, conforme a Base Nacional Comum Curricular, com foco no ensino Fundamental II, estabelecido pelo Ministério da Educação.

O presente material trata-se de uma sequência didática (SD) e será apresentado em forma de roteiro. O material foi elaborado visando propor abordagens teóricopráticas a partir de do uso de recursos geotecnológicos com o tema sobre recursos hídricos. Procurou-se desenvolver uma SD com a perspectiva colaborativa e participativa entre educandos e educadores, estimulando assim, o exercício da cidadania em busca por soluções de problemas ambientais e sociais vigentes.

Evidencia-se a seguir, a descrição desta proposta dividida em duas principais seções, o roteiro contextual do Sujeito e o Mundo, contemplando os objetivos da aprendizagem, bem como a competência da Base Nacional Comum Curricular e seu 
respectivo contexto nos Temas Contemporâneos Transversais (TCTs) especificamente nas macro áreas Meio Ambiente e Ciência e Tecnologia, abordando textos motivadores que contemplam os temas: a bacia hidrográfica é o nosso território, a importância das matas ciliares e de índices que mensuram os impactos da sua ausência. Estes, fundados com a problematização de diagnóstico ambiental, a partir de uma questão norteadora de aplicação das geotecnologias no ensino, que engatilhará o trabalho progressivo subsequente. Na segunda seção, ilustra-se o roteiro de trabalho, o passo a passo, desde a aplicação das Geotecnologias utilizando o Software Google Earth no reconhecimento do território em que se encontra o sujeito, até a proposta de sistematização de avaliação dos resultados.

Espera-se assim, contribuir com os obstinados esforços dos profissionais do ensino que primam por atividades inovadoras e diversificadas possibilitando assim, o exercício da cidadania em busca por soluções de problemas ambientais e sociais, assegurando e educação em sua totalidade ou integralidade e, acima de tudo, e bemestar e o futuro das próximas gerações.

\section{ROTEIRO CONTEXTUAL DO SUJEITO E O MUNDO}

Visando estruturar e orientar o currículo na Educação Básica e, buscando o desenvolvimento na integralidade, biológico, psicológico e social do educando, o governo federal brasileiro deliberou alguns documentos norteadores do ensino, que se efetivaram ao longo da história educacional até o atual momento.

Cronologicamente, o artigo 26 da Lei n 9.394, de 20 de dezembro 1996, Lei de Diretrizes e Bases da Educação Nacional (LDB), regulamentou uma base nacional comum para a educação básica e incluiu a Educação Ambiental como uma diretriz para o Ensino Fundamental (BRASIL, 1996). Em 1998, são alicerçados em dez volumes os Parâmetros Curriculares Nacionais (PCNs), para o Ensino Fundamental, $6^{\circ}$ ao $9^{\circ}$ ano com a intenção de ampliar e aprofundar o debate educacional que evolvesse escola, pais, governo e sociedade, incorporando a temática ambiental em todas das disciplinas (BRASIL, 1997). Em 13 de julho de 2010, a Resolução n4 define as Diretrizes Nacionais 
Gerais para a Educação Básica (DCNs) com o objetivo de orientar o planejamento curricular das escolas e dos sistemas de ensino (BRASIL, 2013). $O$ artigo $1^{\circ}$ da Lei $n^{\circ}$ 13.005, de junho de 2014, regulamentou o Plano Nacional de Educação (PNE), estabelecendo 20 metas para a melhoria da qualidade da Educação Básica, sendo que 4 delas discorriam sobre a construção da Base Nacional Comum Curricular (BRASIL, 2014). Em 17 de junho 2015, pela portaria n 592 foi instituído uma comissão de especialistas para a elaboração da Proposta da Base Nacional Comum Curricular, mas somente em 14 de dezembro de 2018 o ministro da Educação Rossieli Soares homologou o documento Base Nacional Comum Curricular (BNCC) em todas as etapas de ensino.

A Base Nacional Comum Curricular (BNCC) é um documento de caráter normativo que define o conjunto orgânico e progressivo de aprendizagens essenciais que todos os alunos devem desenvolver ao longo das etapas e modalidades da Educação Básica. A Base estrutura os currículos dos sistemas e redes de ensino das Unidades Federativas, como também as propostas pedagógicas de todas as escolas públicas e privadas de Educação Infantil, Ensino Fundamental e Ensino Médio, em todo o Brasil (BRASIL, 2017). Esta, articula-se conforme os termos da LDB, das DCNs e do PNE, estabelecendo conhecimentos, competências e habilidades que se espera que todos os estudantes desenvolvam ao longo da escolaridade básica, valorando os princípios éticos, políticos e estéticos somados aos propósitos que direcionam a educação brasileira para a formação humana integral e para a construção de uma sociedade justa, democrática e inclusiva.

A abordagem dos Temas Contemporâneos Transversais (TCTs), incluso no documento da BNCC, visa permitir ao estudante compreender questões diversas, tais como cuidar do planeta, a partir do território em que vive, cuidar de sua saúde, usar as novas tecnologias digitais, entender e respeitar aqueles que são diferentes e quais são seus direitos e deveres como cidadão, contribuindo para a formação integral do estudante como ser humano, sendo essa uma das funções sociais da escola (BRASIL, 
2018). A Base Nacional Comum Curricular destaca a importância dos TCTs quando diz que é dever dos sistemas de ensino e escolas:

Por fim, cabe aos sistemas e redes de ensino. Assim como as escolas, em suas respectivas esferas de autonomia e competência, incorporar aos currículos e às propostas pedagógicas a abordagem de temas contemporâneos que afetam a vida humana em escala local, regional e global, preferencialmente de forma transversal e integradora (BRASIL, 2017, p. 19).

Estruturada na BNCC, grande área de Ciências Humanas é vislumbrada fundamentalmente para o desenvolvimento cognitivo básico dos educandos no tempo e espaço de forma integradora, que coaduna com os TCTs. Esse raciocínio espaço-temporal é concebido o ser humano como produtor de um espaço de vivência e apoderado dele em determinada circunstância histórica em escala local, regional e global. Nessa completitude, espera-se que o discente perfaça uma avaliação do passado ou no presente, reconhecendo-se como responsável tanto pelo saber produzido quanto pelo controle dos fenômenos naturais e históricos dos quais é agente transformador.

A Geografia, área das Ciências Humanas, predispõe ao aluno fazer essa leitura do mundo em que vive e a pensar espacialmente, desenvolvendo o raciocínio geográfico e reconhecendo os objetos, os fenômenos e os lugares distribuídos em seu território. A percepção de realidade, o ordenamento territorial, as conexões existentes entre componentes físico-naturais e as ações antrópicas, o inserem como elemento fundamental na construção ética (BRASIL, 2017). Construção essa, valorando os direitos humanos, o respeito ao ambiente e a coletividade, fortalecendo assim, os valores sociais.

Construir um agente protagonista do meio, ou seja, o sujeito capaz de atuar para o bem comum com discernimento e veemência por um mundo democrático e humanizado e que reconheça os recursos naturais como parte de sua própria vida, exige do docente um olhar com desvelo para seus educandos, exige planejamento.

Planejar as ações pedagógicas é fundamental para que o docente conduza o processo de aprendizagem com mais segurança e significado (GAMA, 2016). É papel do professor e da escola garantir o desenvolvimento dos sujeitos em todas as suas dimensões, intelectual, física, emocional, social e cultural e se constituir como projeto 
coletivo, compartilhado por crianças, jovens, famílias, educadores, gestores e comunidades locais.

Por suposto, o planejamento educacional fundamentado na formação integral dos sujeitos, promove a criticidade, autonomia e responsabilidade consigo mesmos e com o mundo. A concepção de integralidade é inclusiva, reconhece a singularidade dos sujeitos, instiga a equidade a partir das múltiplas linguagens, espaços e recursos e está alinhada com a sustentabilidade, porque o processo educativo é contextualizado na interação entre o que se aprende e o que se pratica (ALMEIDA, 2018).

Destarte, a construção ações educacionais planejadas sob a perspectiva da integralidade na Geografia, conduz a construção e a reconstrução dos saberes, voltando o olhar do educando para o mundo, para o território em que vive e para as suas finalidades e seu potencial de executabilidade. Abordando essa concepção inovadora de ensino, sob a perspectiva colaborativa, participativa e tecnológica entre educandos e educadores assegurados pelo documento normativo BNCC e TCTs, descreve-se o roteiro subsequente. Deslumbra-se que nesta estratégia, o papel do conhecimento científico será proposto como conhecimento da atividade científica que explicará os fenômenos naturais e sociais de forma racional, produto de uma atividade que envolverá, a partir de uma hipótese, metodologia e um debate dos resultados da investigação.

Tendo isto posto, vamos apresentar o roteiro. Ele é composto por três textos motivadores, uma seção que discute "A bacia hidrográfica é o nosso território", "A importância das matas ciliares" e a outra que apresentará os "Índices de impacto" abordando uma "Proposta de sistematização e avaliação dos resultados", sendo que partimos dos objetivos da aprendizagem e da competência da Base Nacional Comum Curricular. 


\subsection{Objetivos da aprendizagem}

- Compreender os elementos que definem uma bacia hidrográfica e identificar o ser humano como parte e agente modificador da natureza e do ambiente;

- Reconhecer que a ação humana pode gerar grandes impactos ambientais que comprometem qualidade da água em uma bacia hidrográfica e por consequência a saúde humana;

- Identificar as transformações no entorno de uma bacia hidrográfica aplicando as geotecnologias;

- Problematizar e contextualizar a possibilidade do uso de diferentes ferramentas tecnológicas aplicadas ao ensino, na resolução de problemas ambientais vigentes;

- Confrontar os resultados obtidos na pesquisa com a validação metodológica das geotecnologias, comprovando ou refutando a tese inicial para o diagnóstico ambiental dos cursos hídricos.

\subsection{Competências da Base Nacional Comum Curricular}

(5) Cultura digital

Compreender, utilizar e criar tecnologias digitais de informação e comunicação de forma crítica, significativa, reflexiva e ética nas diversas práticas sociais (incluindo as escolares) para se comunicar, acessar e disseminar informações, produzir conhecimentos, resolver problemas e exercer protagonismo e autoria na vida pessoal e coletiva (BRASIL, 2017).

Para implementar o roteiro, apresenta-se a sequência de textos motivadores que criarão o ambiente para o surgimento de questões com os alunos.

\subsection{Texto motivador 1: A Bacia Hidrográfica é o nosso território}


A bacia hidrográfica é uma área de captação natural da água de precipitação que faz convergir o escoamento para um único ponto de saída. A bacia hidrográfica compõe-se de um conjunto de superfícies vertentes e de uma rede de drenagem formada por cursos de água que confluem até resultar em um leito único no seu exutório. Essa estrutura é formada por desníveis dos terrenos e orienta uma hierarquização de ecossistemas aquáticos, desde nascentes, passando por riachos e rios menores, até um leito único. Este último é, naturalmente, mais caudaloso (maior corrente e fluxo de águas) no ponto mais baixo da paisagem (SOUZA, 2020). Observando um córrego ou rio, que compõe uma bacia hidrográfica, podemos identificar dois pontos referenciais: montante e jusante (figura 1).

Figura 1 - Hierarquização de ecossistemas aquáticos

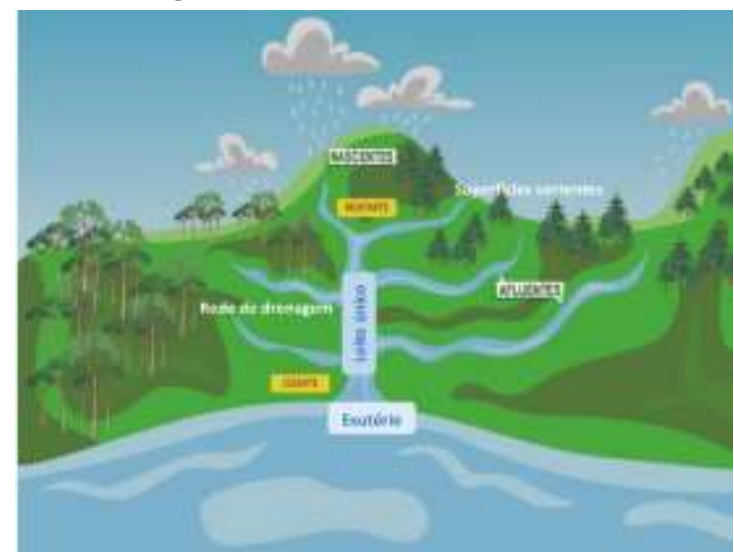

Fonte: Autores (2020)

Consideramos: montante como tudo que está acima de um referencial, ou a parte alta, na direção das superfícies vertentes (nascentes), e jusante, como tudo o que está abaixo do um referencial, ou parte baixa, em direção ao exutório.

Também, podemos identificar três regiões características em uma bacia hidrográfica, conforme a figura 2. 
Figura 2 - Regiões características de uma bacia hidrográfica

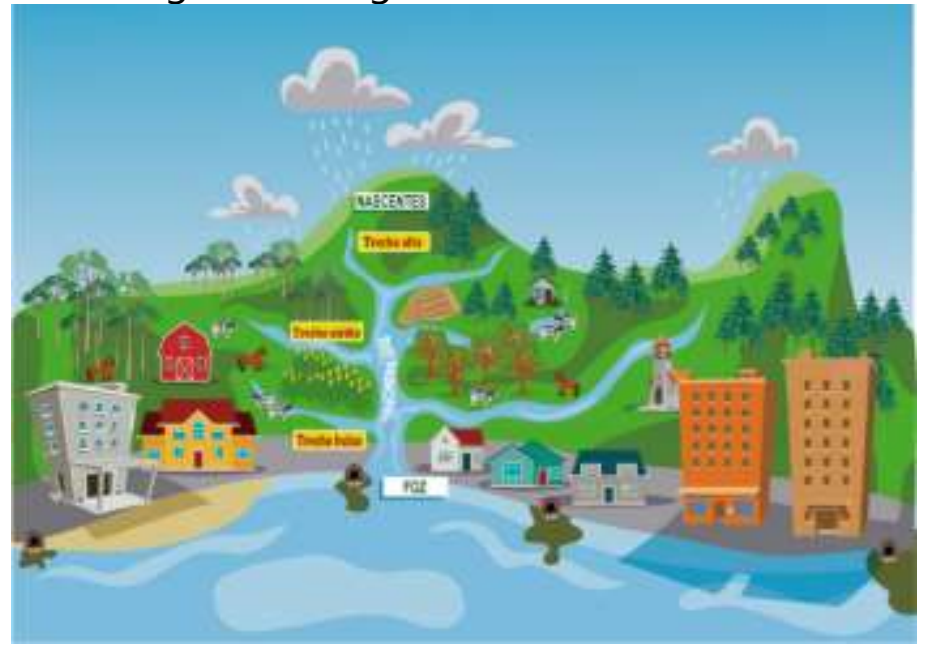

Fonte: Autores (2020)

Região de trecho alto: região mais próxima às nascentes do rio principal e normalmente é caracterizada por um relevo mais elevado e acidentado, que determina a direção das águas no sentido à jusante. Qualquer impacto ocorrido nesta região influenciará toda a bacia local e à jusante, na direção da foz (FRANÇA, 2019).

Região de trecho médio: região localizada entre as nascentes e a foz, e relacionada ao curso do rio principal. Essa região, normalmente, é caracterizada por um relevo alto lateralmente de onde recebe os afluentes. Também, a região é influenciada por impactos urbanos locais, vindos da região alta e com influência na parte baixa da bacia, recebendo de montante (trecho alto) e influenciando a jusante (trecho baixo) (FRANÇA, 2019).

Região de trecho baixo: é a região mais próxima à foz do rio principal da bacia. Essa região, é caracterizada por apresentar um relevo mais baixo e plano, com partes altas lateralmente de onde são recebidos alguns afluentes. Além dos impactos urbanos locais, esta região recebe a influência de toda a bacia à montante, advinda dos trechos alto e médio (FRANÇA; CALISTTO, 2019).

Entender uma bacia hidrográfica como nosso território, remete à compreensão da multiplicidade de conflitos de interesses que envolvem pessoas e processos dessa região. Todas as áreas urbanas, industriais, agrícolas ou de preservação fazem parte de alguma bacia hidrográfica. 
As atividades humanas podem, em qualquer área desse território, influenciar na região de drenagem da bacia, alterando a qualidade da água e por consequência prejudicando a saúde humana (PORTO, 2008). Por isso, a bacia hidrográfica é o nosso território e, é de suma importância que nós mantenhamos as características naturais ao entorno de riachos e rios que formam essas bacias. Segue abaixo, na figura 3, um modelo de bacia hidrográfica, nosso território.

Figura 3 - Nosso Território - Bacia Hidrográfica do Itajaí-Açu, SC- Brasil

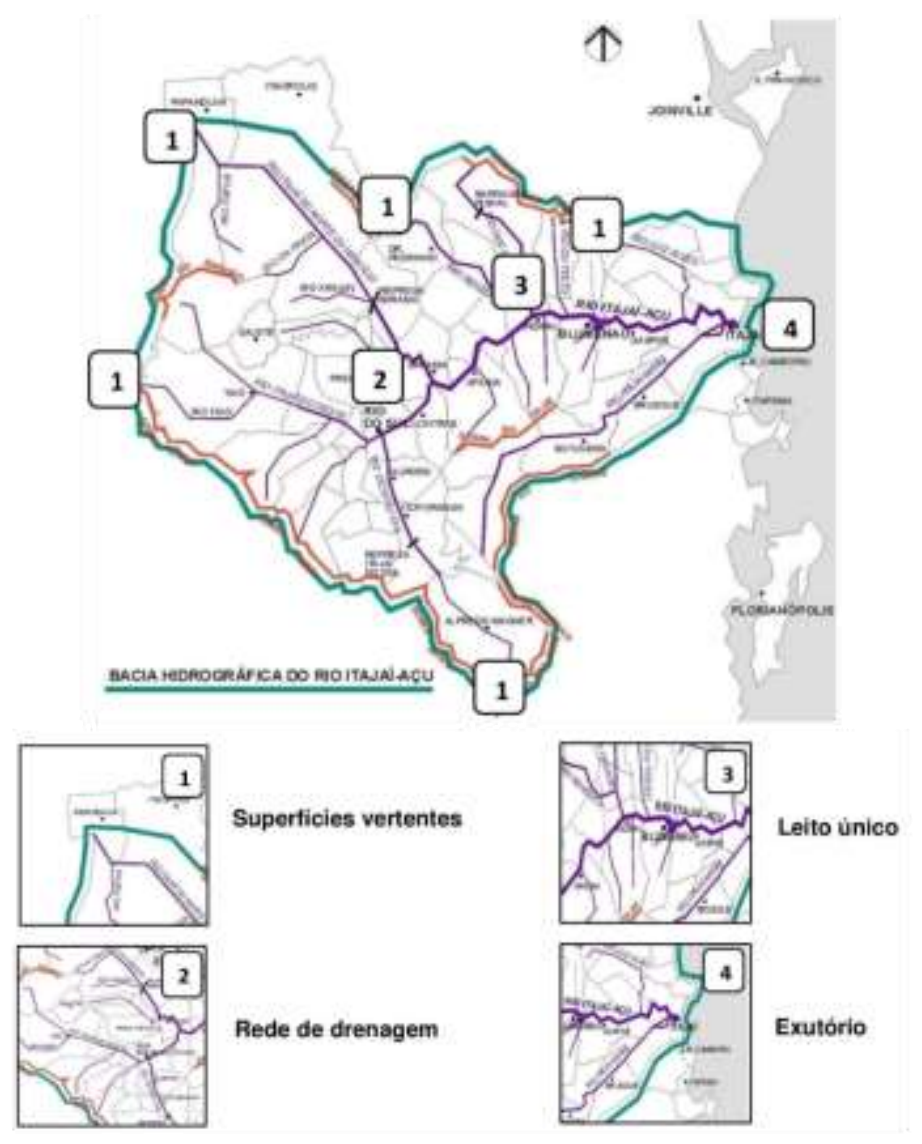

Fonte: Klaumann, A., 2017, organização autores (2020)

Quando conseguimos conhecer e se reconhecer como parte do território em que vivemos, passamos a inferir na sua conservação e manutenção, assim estaremos contribuindo na construção agentes transformadores do pensar e do ambiente! 


\subsection{Texto motivador 2: A importância das matas ciliares}

As matas ciliares ou florestas ripárias, podem ser compreendidas como áreas cobertura vegetal nativa e por um sistema florestal comumente situada em faixas de margens de rios, outros corpos de água, em torno de nascentes, lagos, represas artificiais ou naturais (CASTRO, 2017). Um exemplo desse tipo de cobertura vegetal pode ser exemplificado na figura 4.

Figura 4 - Rio Itajaí-açu - Município de Apiúna, SC

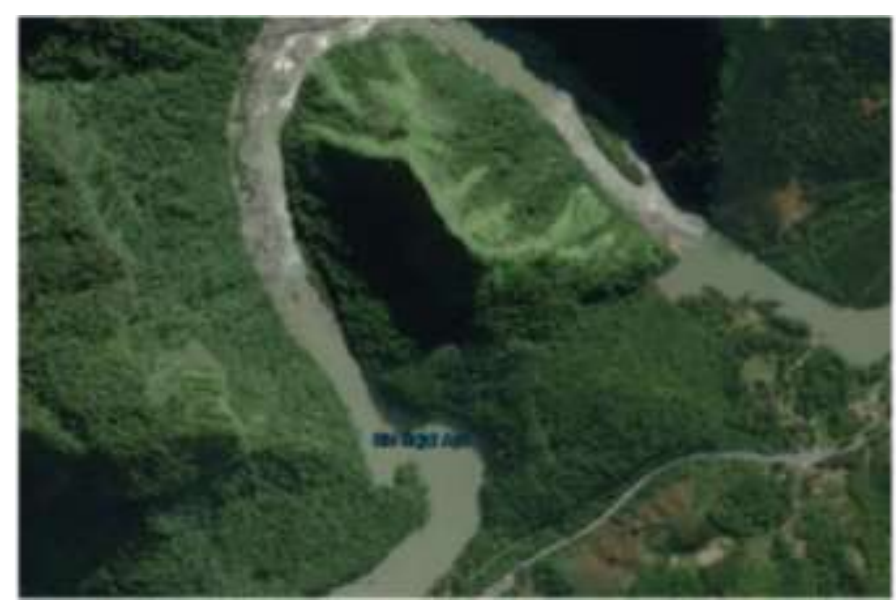

Fonte: earthexplorer.usgs.gov, organização autores (2020)

O nome "ciliar" é dado por ficarem cercando essas águas, e serem tão importantes para a sua conservação quanto são os cílios para os nossos olhos.

Elas desempenham um importante papel na proteção dos rios, tornando fundamental a sua conservação e recuperação. A manutenção da qualidade da água, estabilidade dos solos, regularização dos ciclos hidrológicos e a conservação da biodiversidade dependem da preservação da mata ciliar.

Em relação à manutenção da qualidade da água, a mata reduz o assoreamento e a força das águas que chegam aos rios, lagos e represas, o que mantém sua qualidade ao impedir a entrada de poluentes para o meio aquático (VENZKE, 2018). Além disso, formam corredores que contribuem para a conservação da biodiversidade, fornecendo alimento e abrigo para a fauna, constituindo barreiras naturais contra a disseminação de pragas e doenças da agricultura e, durante seu crescimento, absorvem e fixam dióxido de carbono, um dos principais gases responsáveis pelas mudanças climáticas. 
O código florestal brasileiro determina uma distância mínima que se deve manter da mata ciliar nas margens de um rio, considerada uma Área de Preservação Permanente (APP), pela Lei No 12. 651 de maio de 2012, que institui o novo código florestal brasileiro (figura 5). A ilustração abaixo demonstra a quantidade mínima de mata ciliar que deve ser protegida por lei, entretanto a expansão das áreas agrícolas, o aumento dos aglomerados urbanos, a exploração dos recursos naturais são exemplos de ações antrópicas que provocam alterações nesse ambiente natural e por consequência nos recursos hídricos. Estas ações, associadas ao desenvolvimento contínuo e mal planejado, geram impactos ambientais e socioeconômicos em diversas regiões do país.

Figura 5 - Dimensões da mata ciliar regulamentadas pelo Art. $4^{\circ}$ da Lei $n^{\circ} 12.651 / 2012$

\section{LARGURA DA APP (MATA CILIAR) COMPARADA À LARGURA DO RIO}

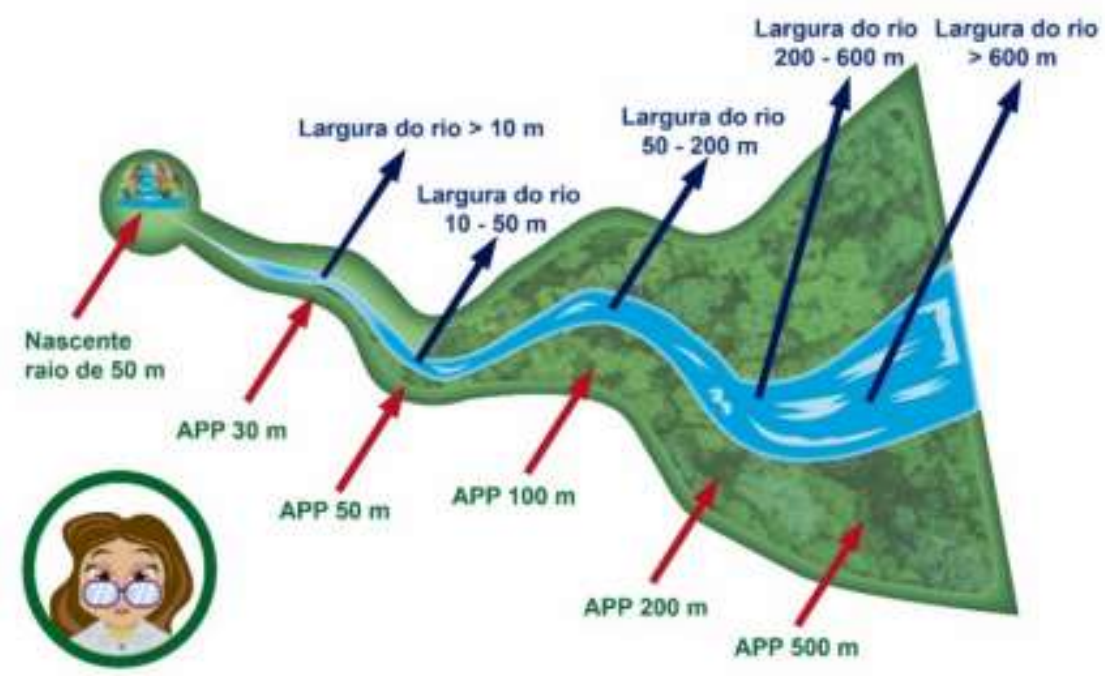

Fonte: Autores (2020)

Um dos grandes desafios da sociedade, no que diz respeito à conservação ambiental, tem sido reunir esforços e recursos para a preservação e recuperação dessas áreas, que são consideradas estratégicas para a manutenção e conservação dos recursos naturais e da saúde humana.

\subsection{Texto motivador 3: Índices de impacto}


Segundo o dicionário, a palavra índice significa " entidade destinada a controlar e atualizar a ordem sequencial da informação armazenada no banco de dados associado", e a palavra impacto como "choque; encontrão, embate, alteração" (BUENO, 2007 , p. 431; 421). Assim sendo, podemos concluir que do ponto de vista ambiental índices de impacto são padrões regulamentados para analisar alterações ocorridas no ambiente.

Segundo a Resolução Nº 001, de 23 de janeiro de 1986 do Conselho Nacional do Meio Ambiente - CONAMA, define-se impacto ambiental, como a alteração das propriedades físico-químicas e biológicas do meio ambiente, alteração esta provocada direta ou indiretamente por atividades humanas, as quais afetam saúde, segurança, bem-estar da população, atividades socioeconômicas, biota, condições estéticas e sanitárias do meio e qualidade dos recursos.

O indicador de impacto ambiental diz respeito aos elementos ou parâmetros que fornecem a medida da magnitude de um impacto ambiental. Este pode ser quantitativos (representado em escala numérica) ou qualitativos (classificado em categorias ou níveis), podendo ser biológicos :população microbiana, biomassa; físicos: perda do solo, solubilidade e químicos: macro e micronutrientes, metais pesados, $\mathrm{pH}$ (AMBIENTE BRASIL, [S.I] [2020]).

No Brasil, o Instituto Brasileiro de Geografia e Estatística - IBGE, é um órgão do Governo Federal subordinado ao Ministério do Planejamento, Desenvolvimento e Gestão, que foi criado com o intuito de levantar e fornecer dados e informações sobre o território brasileiro e sua população. Ele se constitui no principal provedor de dados e informações do país, que atendem às necessidades dos mais diversos segmentos da sociedade civil, bem como dos órgãos das esferas governamentais federal, estadual e municipal (IBGE, 2020).

Hoje, o IBGE oferece ao país uma vasta biblioteca na área ambiental que é utilizada como normatização para índices de impactos ambientais (figura 6). $O$ órgão, produz e analisa de informações geográficas; estrutura e implanta informações ambientais, documenta e dissemina essas informações através de publicações voltadas 
para a sociedade com o objetivo de apresentar conceitos e metodologias fundamentais sobre as atividades de geociências.

Figura 6 - Manuais Técnicos do IBGE

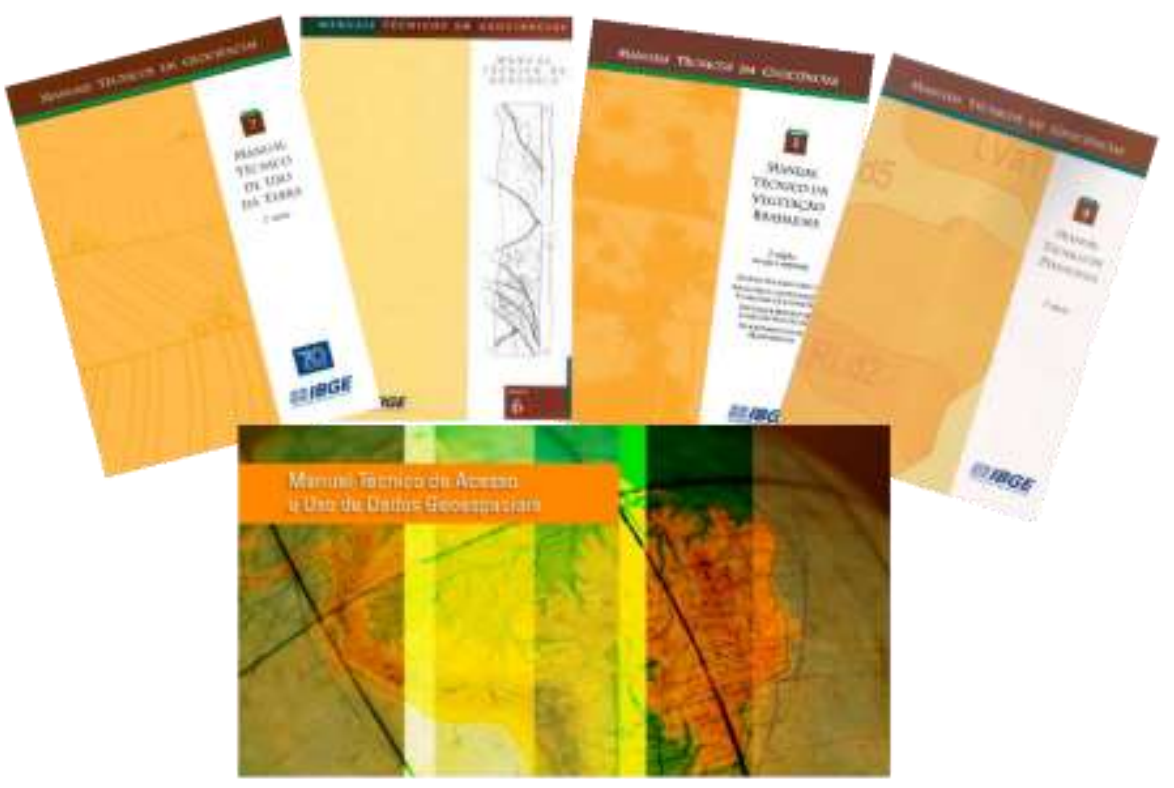

Fonte: IBGE, 2020, Autores (2020)

Atualmente, uma ferramenta que auxilia o mapeamento de problemas e situações urbanas e/ou ambientais juntamente com informações demográficas, geográficas e topográficas fornecidas pelo IBGE, são as geotecnologias.

A geotecnologia é uma técnica que usa sistemas automatizados com computadores e programas computacionais para a coleta, tratamento, processamento e modelagem de dados e informações georreferenciados como: a Topografia, a Fotogrametria, a Cartografia, o Sensoriamento Remoto, o posicionamento por Satélites, a Geoestatística, o Banco de Dados Geográficos, o WebMapping e o SIG, conforme demostrado na figura 7 (ROSA, 2005). O produto ou arquivo produzido por estes instrumentos serão chamadas geoinformações, como por exemplo uma imagem de satélite.

Essas imagens de satélite permitem a visualização da distribuição de florestas, culturas agrícolas, qualidade de água, feições geomorfológicas, temperatura da 
superfície terrestre, da presença de nuvens e outras, tudo a partir de um pixel. Esses parâmetros podem ser obtidos em laboratório informatizado ou em levantamento a campo.

A partir dessas informações é possível conhecer a dinâmica de ocupação e utilização da terra, bem como acompanhar a evolução e a transformação do território brasileiro no controle dos impactos das atividades humanas sobre o meio ambiente, bem como propor a elaboração de políticas públicas de planejamento territorial proporcionando o desenvolvimento sustentável da sociedade (SILVA, M. S da; LEMOS, S. S de; MORAES, A. B de, 2018).

Figura 7 - Geotecnologias

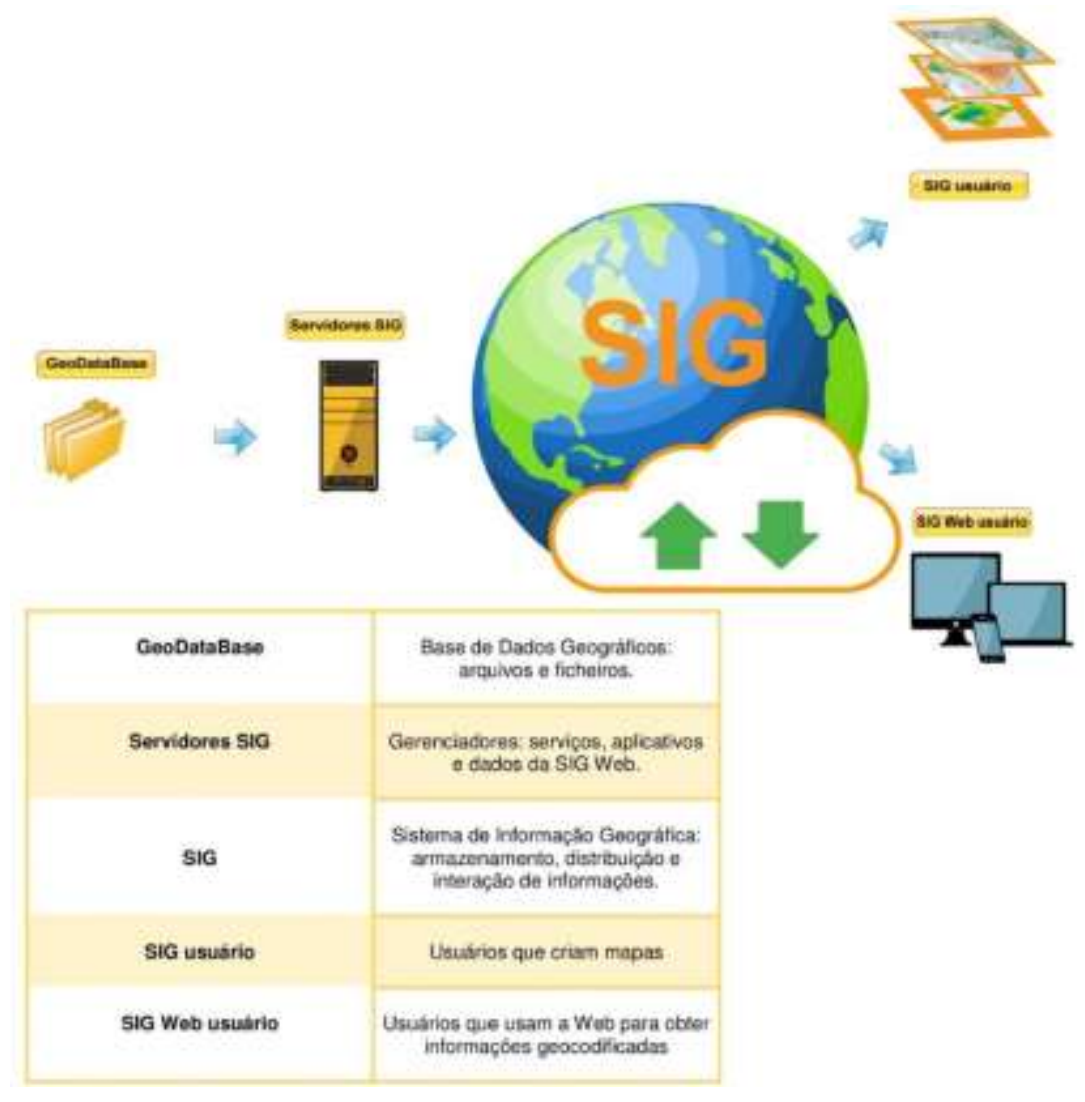

Fonte: Autores (2020)

Diante do exposto, emerge ao que denominamos de questão disparadora: como podemos aplicar a geotecnologia em nosso estudo científico? Então, mãos à obra! 
O roteiro prático a seguir é direcionado aos professores, tendo em vista as fundamentações teóricas que a proposta se baseia.

\section{ROTEIRO PRÁTICO DO SUJEITO E O MUNDO}

No imo da unidade escolar, a temática proposta neste roteiro práticotecnológico "sujeito e o mundo" permite contemplar as premissas da Base Nacional Comum Curricular (BNCC) referente aos Temas Contemporâneos Transversais (TCTs), inferindo nas macro áreas Meio Ambiente e Ciência e Tecnologia alicerçadas na perspectiva de aprendizagem de Rousseau (1712-1778), Vygotsky (1896-1934), Lévy (1956) e Jonassen (1947-2012).

Historicamente, a inovação da prática pedagógica proposta por Jean-Jaques Rousseau (1712-1778) deslocou o centro do processo de aprendizagem do docente e dos conteúdos, para as necessidades e interesses dos educandos, contradizendo as metodologias de aprendizagem apresentadas até então. Entretanto, essa mudança só obteve representação com a criação de novas escolas e métodos educacionais, orientados à aprendizagem ativa frente à problemas do cotidiano (WENDT; DALBOSCO, 2012).

Nessa conjuntura, a contribuição de Vygotsky (1988), na perspectiva da aprendizagem, com sua proposta técnica e inovadora para a época, quanto ao pensamento e a linguagem e também a natureza do processo de desenvolvimento da criança e o papel da instrução no desenvolvimento, merecem referência.

Vygotsky (1988) descreveu qual o papel a desempenhar pelo contexto social no desenvolvimento dos processos cognitivos das crianças. A interação social, nesse sentido, exerce papel crucial no desenvolvimento cognitivo. Essa abordagem apoia-se na concepção de um sujeito interativo que elabora conhecimentos sobre objetos, em processos necessariamente mediados pelo outro e constituídos pela linguagem.

A relação entre aprendizagem e desenvolvimento, Vygotsky (1988) aponta a existência de um nível a qual chamou de proximal ou potencial, que deve ser considerado na prática pedagógica, pois os educadores ao observar o desempenho 
observado no final do processo de ensino aprendizagem, ou seja, quando o aluno não consegue realizar sozinho determinada tarefa, mas consegue realizar com a ajuda de outros colegas, está revelando seu nível de desenvolvimento proximal, que já contém aspectos e partes mais ou menos desenvolvidas de instituições, noções e conceitos.

No final da década de 70, a difusão dos computadores intensificaram as mutações nos meios de interação social, principalmente nos modos de comunicação. A emergência dessas novas Tecnologias da Informação e Comunicação (TICs) acarretou profundas modificações nas instituições sociais, das quais, a educação não poderia estar ilesa, construindo assim, métodos interativos de aprendizagem, como já proposto por Vygotsky, associados a novas tecnologias.

Segundo o filósofo francês Pierre Lévy (1993) a origem do computador foi essa inovação imprescindível que transformou a informática em um meio de massa para a criação, comunicação e simulação. Conforme ele, a intervenção da tecnologia é o principal ponto de apoio de um processo ininterrupto de aprendizagem e de ensino da sociedade por si mesma.

Lévy (2001, p. 92) ressalta que "todas as instituições humanas irão se integrar e convergir para uma inteligência coletiva sempre capaz de produzir e explorar novas formas." Nessa interface homem/máquina proposto por Lévy, o conjunto de programas e aparelhos materiais que permitem a comunicação entre um sistema informático e seus usuários desenvolvem a interatividade entre os sujeitos por consequência a aprendizagem.

No ensejo tecnologia e aprendizagem, David H. Jonassen (1996) classifica a informática e a aprendizagem em quatro aspectos: aprender a partir da tecnologia, aprender acerca da tecnologia, aprender através da tecnologia e aprender com a tecnologia. Essas quatro formas determinam a aprendizagem e não a tecnologia em si, mas a forma de utilizar corretamente a ferramenta, usando-a sobretudo, como estratégia cognitiva de aprendizagem.

Segundo Jonassen (1996, p.71) "As tecnologias educacionais atuam como ferramentas possível de aproximação dos sujeitos (alunos) para as soluções de diversos 
problemas". Conforme o referido autor, a aprendizagem deve ser construída de problemas e questões relevantes que compõem os conflitos do mundo concreto, nos quais os alunos devem construir o conhecimento com desempenho efetivo.

Pensando na aproximação de aprendizagem com o mundo concreto, desenvolveram-se diferentes instrumentos para se compreender e associar à análise do espaço geográfico aplicados no ensino de Geografia, a partir de geotecnologias, como os softwares GIS (Geographical Information System), GPS (Global Positioning System) e Google Earth.

As geotecnologias surgiram concomitantemente a partir do desenvolvimento dos computadores e se difundiram, especialmente, com a divulgação maciça da Internet a partir da década de 1980. A literatura sustenta a Geotecnologia como a utilização da informação para a análise do espaço geográfico, realizada por meio da tecnologia. 0 autor Fitz, 2005 afirma que:

[...] geotecnologias, estas entendidas como sendo as novas tecnologias ligadas às geociências e às outras correlatas. As geotecnologias trazem, no seu bojo, avanços significativos no desenvolvimento de pesquisas, em ações de planejamento, em processos de gestão e em tantos outros aspectos à questão espacial (FITZ, 2005, p. 3).

Utilizar as geotecnologias (softwares), com o intuito de embasar e fomentar o processo de aprendizagem no ensino de Geografia, faz com que o educando compreenda o objeto de estudo como uma prática dialética com a realidade. Por meio da obtenção de dados espaciais no desenvolvimento de pesquisas, o discente localizase como parte do espaço geográfico e passa inferir a ele com responsabilidade e cidadania.

Nesse ensejo de interação social para o desenvolvimento cognitivo, proposto por Vygotsky, a interação entre o homem e a máquina proposto por Lévy (1993), em que o os sujeitos irão interagir confluindo para um desenvolvimento coletivo de aprendizado e de Jonassen (1996), onde a aprendizagem acontece por experiência concreta, observação reflexiva, experimentação ativa na resolução de conflitos concretos do mundo, consolida-se metodologicamente o presente roteiro. 
Os conceitos serão construídos a partir da análise de dados geográficos utilizando como ferramenta o software Google Earth, que são considerados gatilhos cognitivos, desencadeados pelas propostas teóricas-práticas-tecnológicas da concepção do projeto, que preconiza a gestão e proteção das águas.

Além disso, a proposta torna possível engajar a escola em projetos comunitários de Educação Ambiental com viés tecnológico e participativo, ou seja, protagonistas de sua própria vida e atuando com responsabilidade e cidadania, tomando decisões com base em princípios éticos, democráticos, inclusivos, sustentáveis e solidários (BRASIL, 2017).

O projeto prático sequencialmente descrito, tem como mote conector a Educação Ambiental, configurado temas contemporâneos transversais, que permite abarcar os diferentes objetos do conhecimento empregando a Ciência tecnológica à prática de ensino na área da Geografia. Para sistematizar o conhecimento, propõe-se uma atividade que analisará o uso e ocupação do solo entorno de uma bacia hidrográfica, território o qual o estudante está inserido, e reforçará o papel da cientificidade tecnológica na Educação Básica, através da coleta de dados espaciais, a fim de, despertar a criticidade do educando para com os problemas ambientais vigentes. 


\subsection{Aplicação das Geotecnologias}

Como o nosso foco de estudo é uma bacia hidrográfica, propomos a você educador, aplicar o uso de geotecnologia em seu ambiente escolar, como ferramenta de coleta, processamento e análise de dados. Vamos mostrar como as ações humanas impactam o uso e ocupação da terra e também, por consequência sistema hídrico.

A partir de agora educador, organize as equipes de pesquisa (grupos de alunos), e vamos ao laboratório de informática de sua escola ou sala informatizada. Para essa etapa metodológica precisaremos de algumas ferramentas que estão descritas na figura 8.

Figura 8 - Materiais necessários para atividade

Material necessário para esta atividade:
- Computador conectado à internet;
$>$ Programa de Computador "Google Earth" que você baixará
gratuitamente pelo Google no endereço:
https://www.google.com.br/earth/download/gep/agree.html

Fonte: Autores (2020)

Nossa avaliação será, portanto, sobre a paisagem de entorno do ecossistema aquático, ou seja, a respeito dos usos e ocupação da terra que podem estar influenciando os hábitats físicos locais neste ecossistema como: urbanização, agricultura, pastagem e vegetação (propostos pelo manual técnico do uso da terra IBGE).

Esta será uma etapa de "laboratório" de seu projeto de pesquisa, ou seja, uma interpretação de dados. O programa aplicado como geotecnologia será Google Earth, que apresenta um modelo tridimensional do globo terrestre (imagem de satélite) que apoiará na definição dos impactos que estão atuando em sua região de escolha de estudo. Para tanto, vamos seguir algumas etapas:

Etapa 1: conhecendo a geotecnologia

- $\quad$ Abra o Google Earth, clicando duas vezes com o botão esquerdo do mouse;

- $\quad$ Digite o endereço do local de estudo no campo em branco e clique em pesquisar, conforme indicação da seta amarela, na figura abaixo (figura 9). 
Figura 9 - Tela inicial do Google Earth Pro para localizar a área de estudo

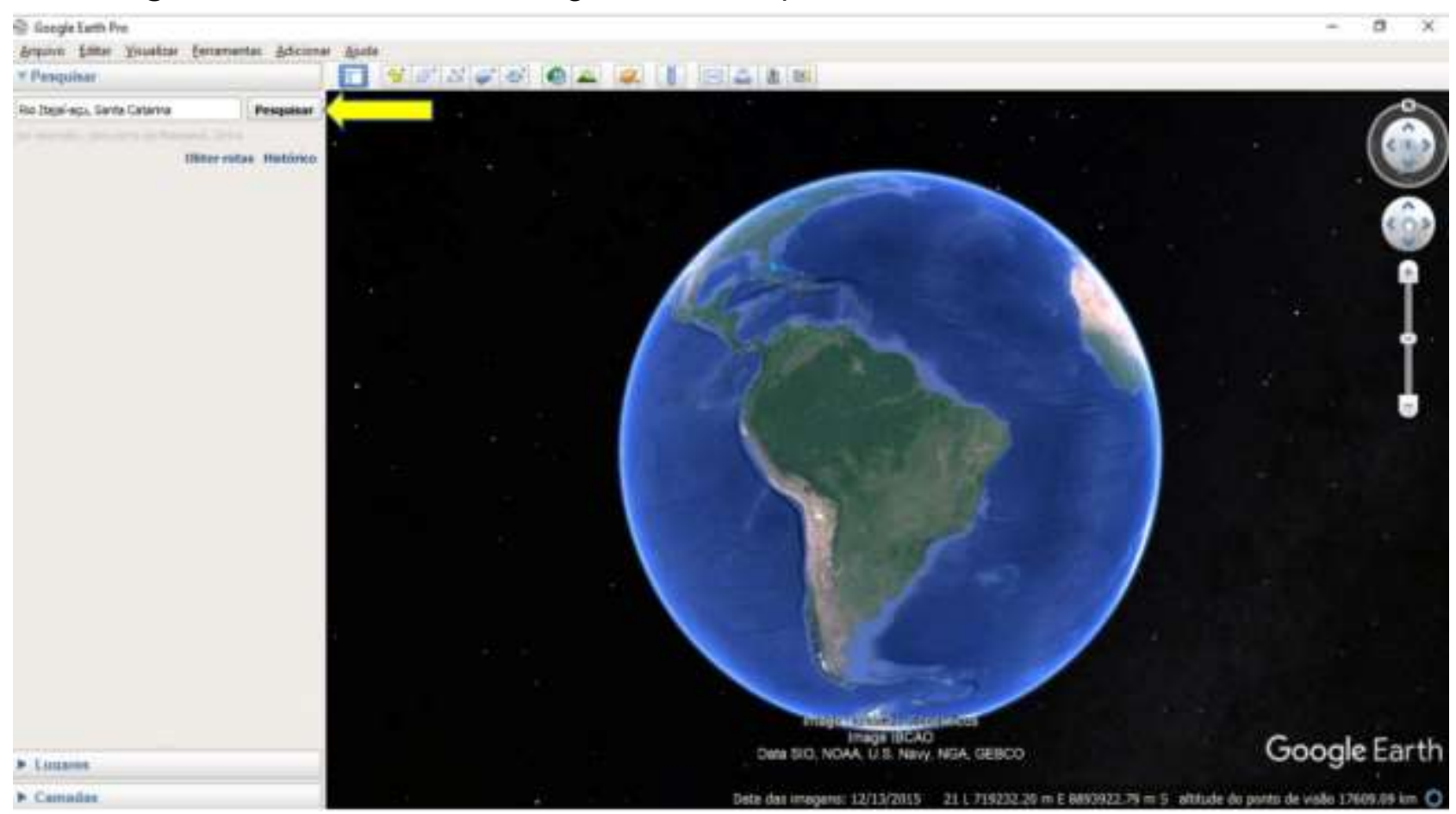

Fonte: Autores (2020)

Lembre-se que o endereço pode ser uma rua perto de um rio, riacho ou mesmo de um local próximo a um curso hídrico.

Etapa 2: localização da área de estudo

- Certifique-se que foi encontrado o ponto solicitado no mapa, como mostra na imagem com seta amarela (figura 10);

- Clique em "alfinete" (indicado com seta vermelha) e o arraste até a sua área de estudo desejada;

- Preencha a caixa de diálogo aberta com o nome de sua "área de estudo" e clique em "ok" para confirmar; 
Figura 10 - Localização da área de estudo

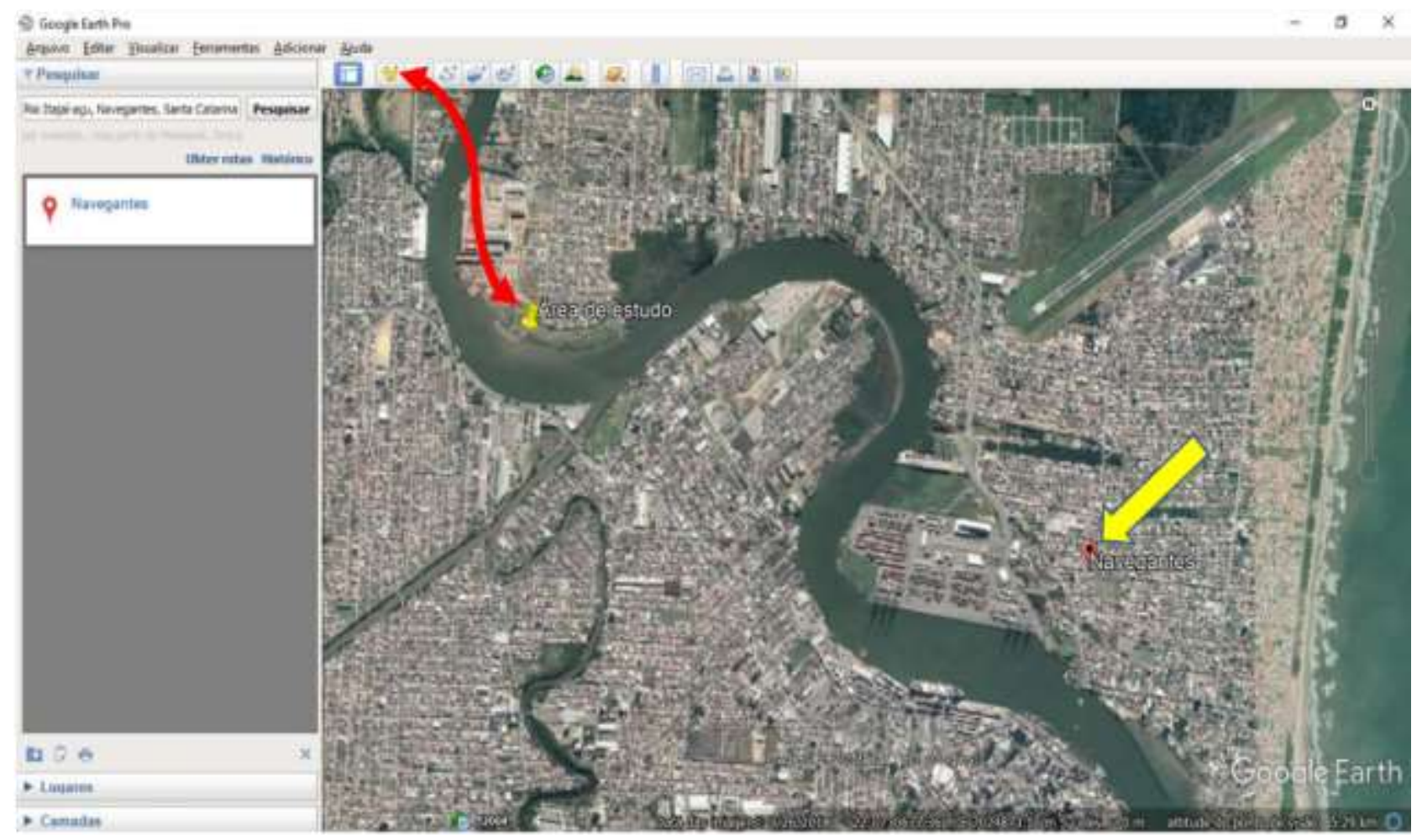

Fonte: Autores (2020)

Etapa 3: demarcação da área a ser avaliada

A demarcarão da área a ser avaliada, parte do local aonde foi inserido o alfinete, conforme indicado. O buffer que será construído às margens do rio e totalizará uma área em metros quadrados, o qual dará uma previsão da influência do uso e ocupação da terra sobre a qualidade das águas.

Para chegar no buffer (figura 11) vamos seguir os seguintes passos:

- Clique em "adicionar polígono" (indicado pela seta vermelha);

- Com o mouse, demarque toda a área desejada clicando com o botão esquerdo, em pontos, até fechar o polígono (A);

- Preencha a caixa de diálogo aberta na aba nome como: "área de avaliação";

- Na aba estilo/cor, altere a cor e a largura da linha para que fique em evidência, também, na área selecione sem cor e circunscrito.

- Clique em ok para fechar a caixa de diálogo (B). 
Figura 11 - Demarcação da área a ser avaliada
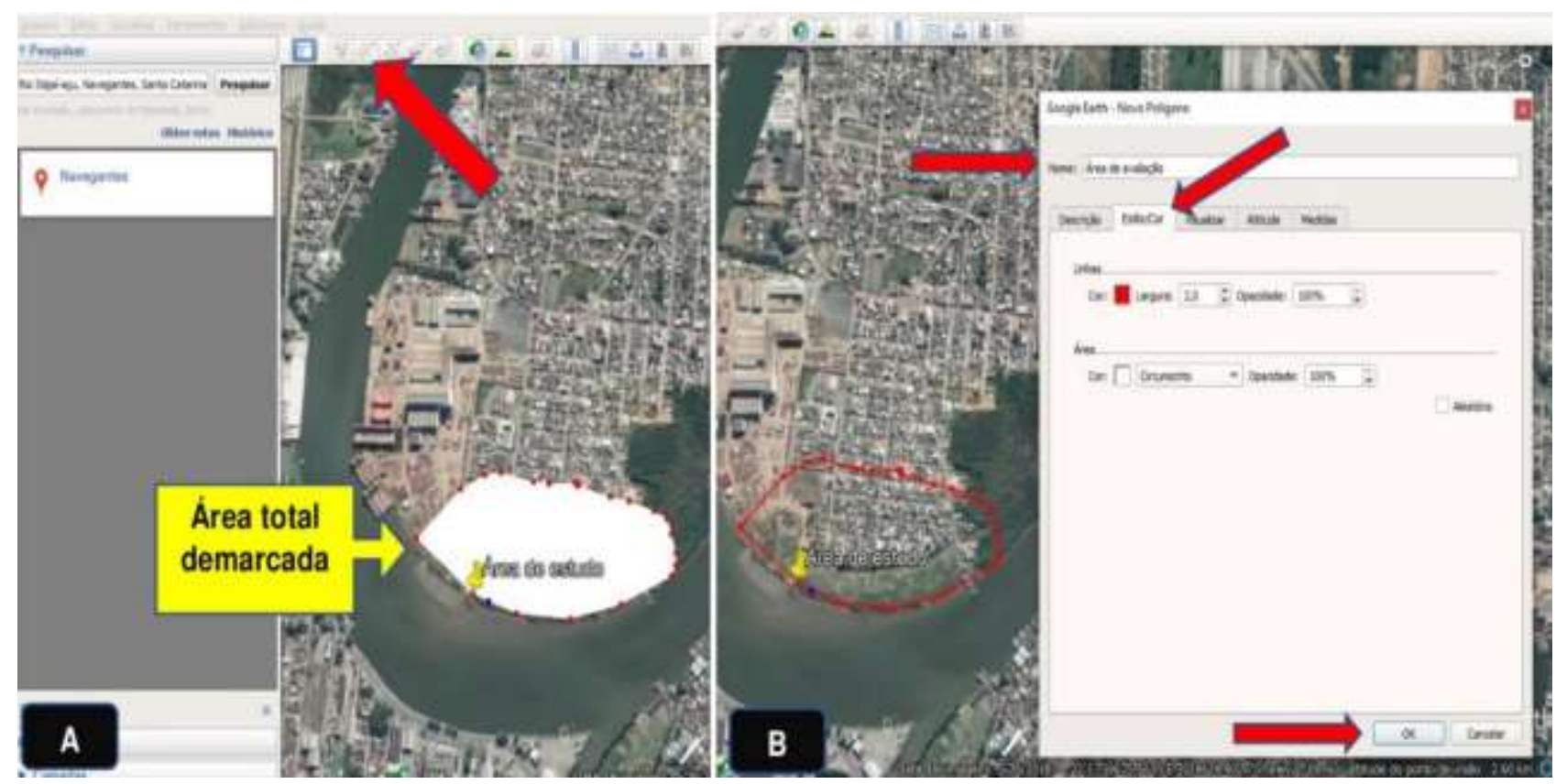

Fonte: Autores (2020)

Etapa 4: quantificação do uso e ocupação da terra

Nossa próxima etapa será determinar as influências do uso e ocupação da terra, com base em quatro parâmetros de características de impacto: 1. Pastagem (baixa influência); 2. Solo exposto (moderada influência); 3. Urbanização (alta influência) e 4. Vegetação (influência positiva). As cores que representarão os níveis de impacto de cada influência serão: laranja (Pastagem/Área Abandonada); amarelo (Solo exposto); vermelho (Urbano/ Residências) e verde (Vegetação), conforme a figura 12. 
Figura 12- Fisionomias de classificação do uso e ocupação da terra

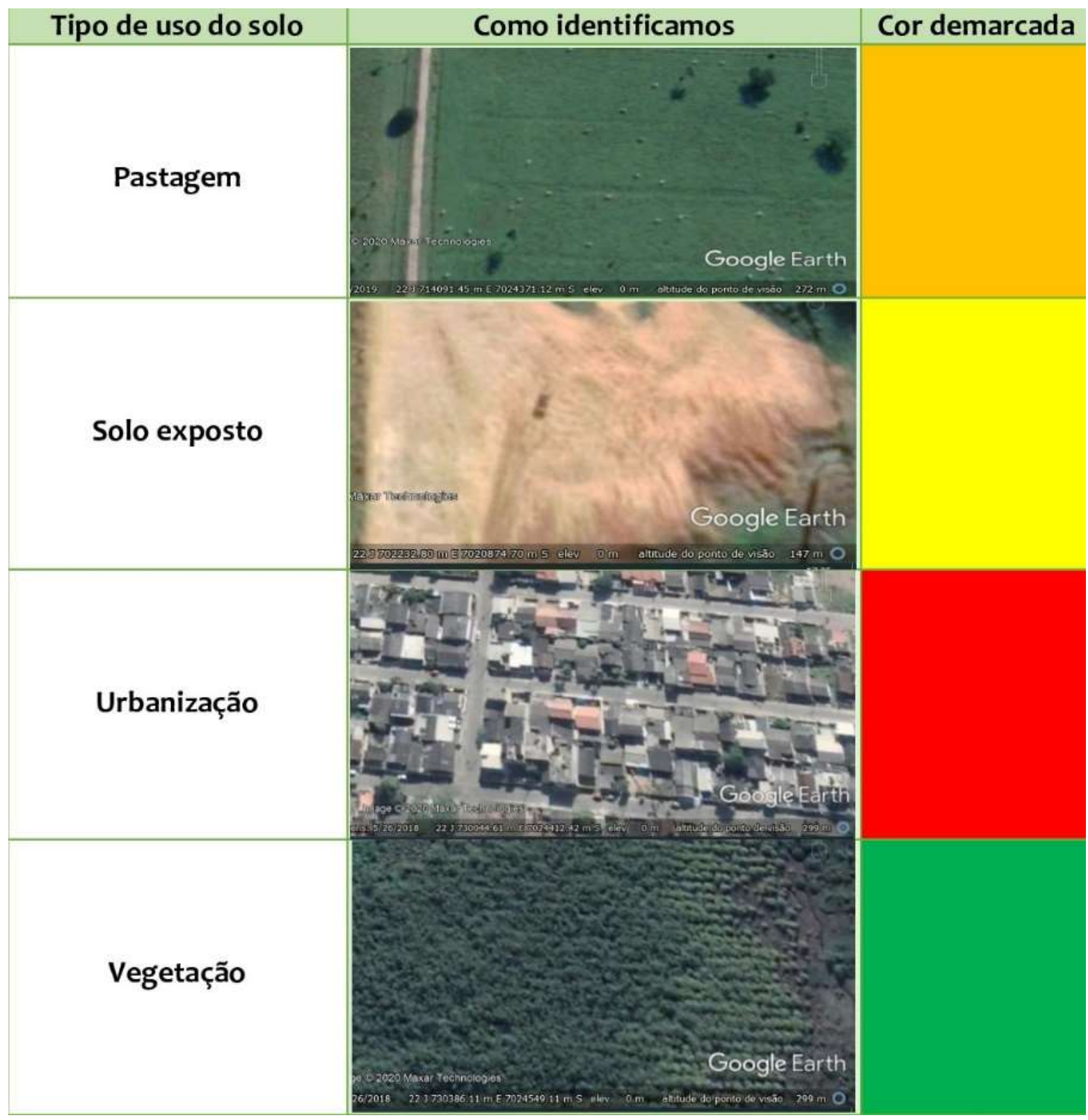

Fonte: Autores (2020)

Lembrando que podemos ter outas fisionomias de uso e ocupação da terra, dependerá da escolha de sua área de estudo. A figura 12 servirá de apoio ou como legenda para a visualização que você encontrará nas imagens de satélite.

Agora vamos quantificar as áreas de uso e ocupação da terra no interior da área de estudo. Para isso, vamos realizar os seguintes passos para cada fisionomia identificada como na figura 13. 
Figura 13 - Identificando as fisionomias do uso e ocupação da terra

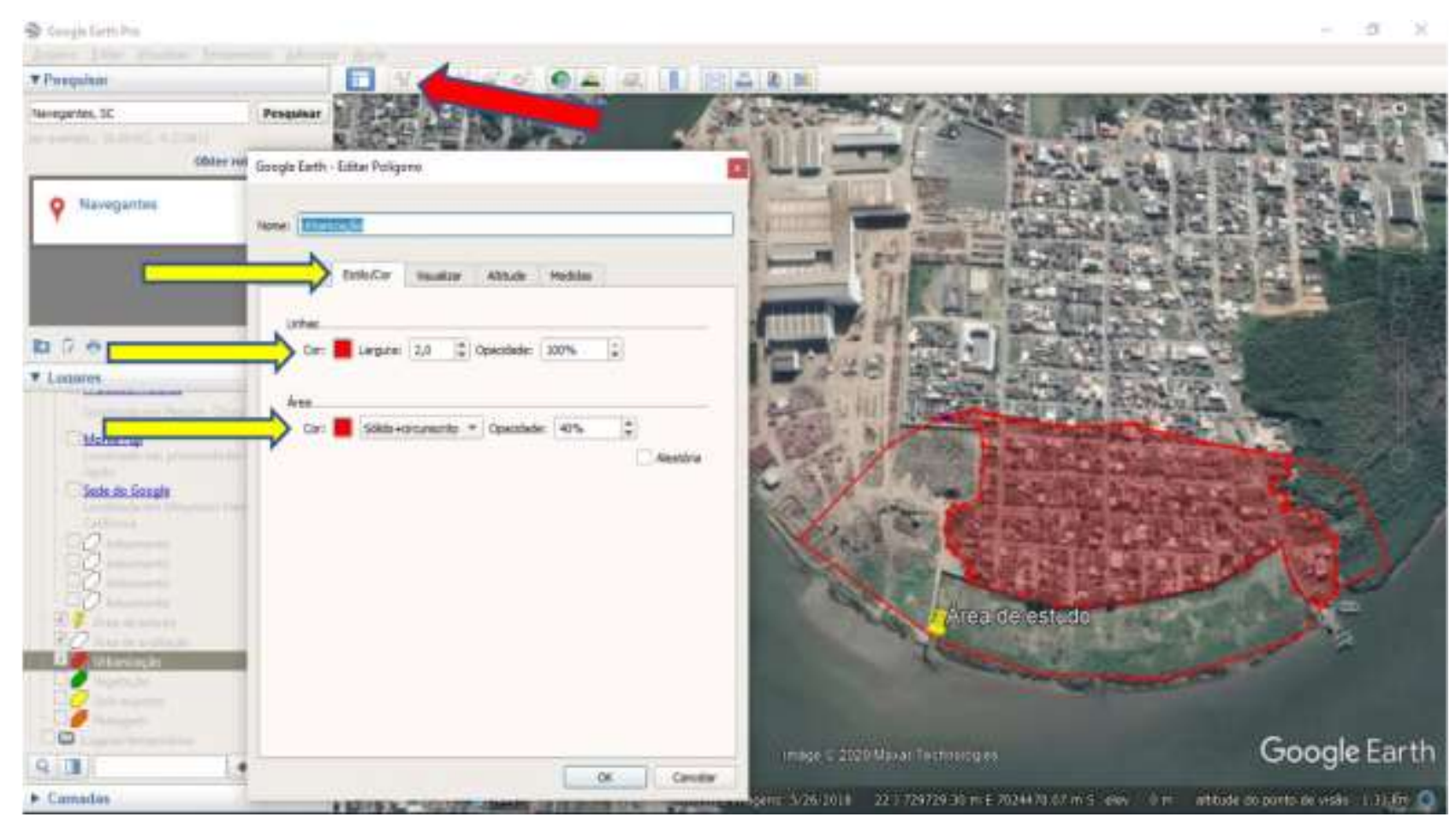

Fonte: Autores (2020)

- Clique em "adicionar polígono" (indicado pela seta vermelha);

- Com o mouse, demarque toda a área desejada clicando com o botão esquerdo, em pontos, até fechar o polígono;

- Preencha a caixa de diálogo aberta na aba nome como: "pastagem ou solo exposto ou urbanização ou vegetação," conforme a sua classificação;

- Na aba estilo/cor, para cada fisionomia, altere a cor e a largura da linha para que fique em evidência, também, na área selecione a cor conforme a tabela acima e defina sólido + circunscrito com opacidade de 40\%;

- Clique em ok para fechar cada caixa de diálogo.

Ao finalizar a classificação para cada fisionomia você obterá sua área de estudo conforme a figura figura 14.

Efetuado a classificação para cada uso e ocupação da terra você terá na barra lateral ícone "lugares" as caixas que correspondem a sua legenda. 
Figura 14 - Legenda das fisionomias de uso e ocupação da terra

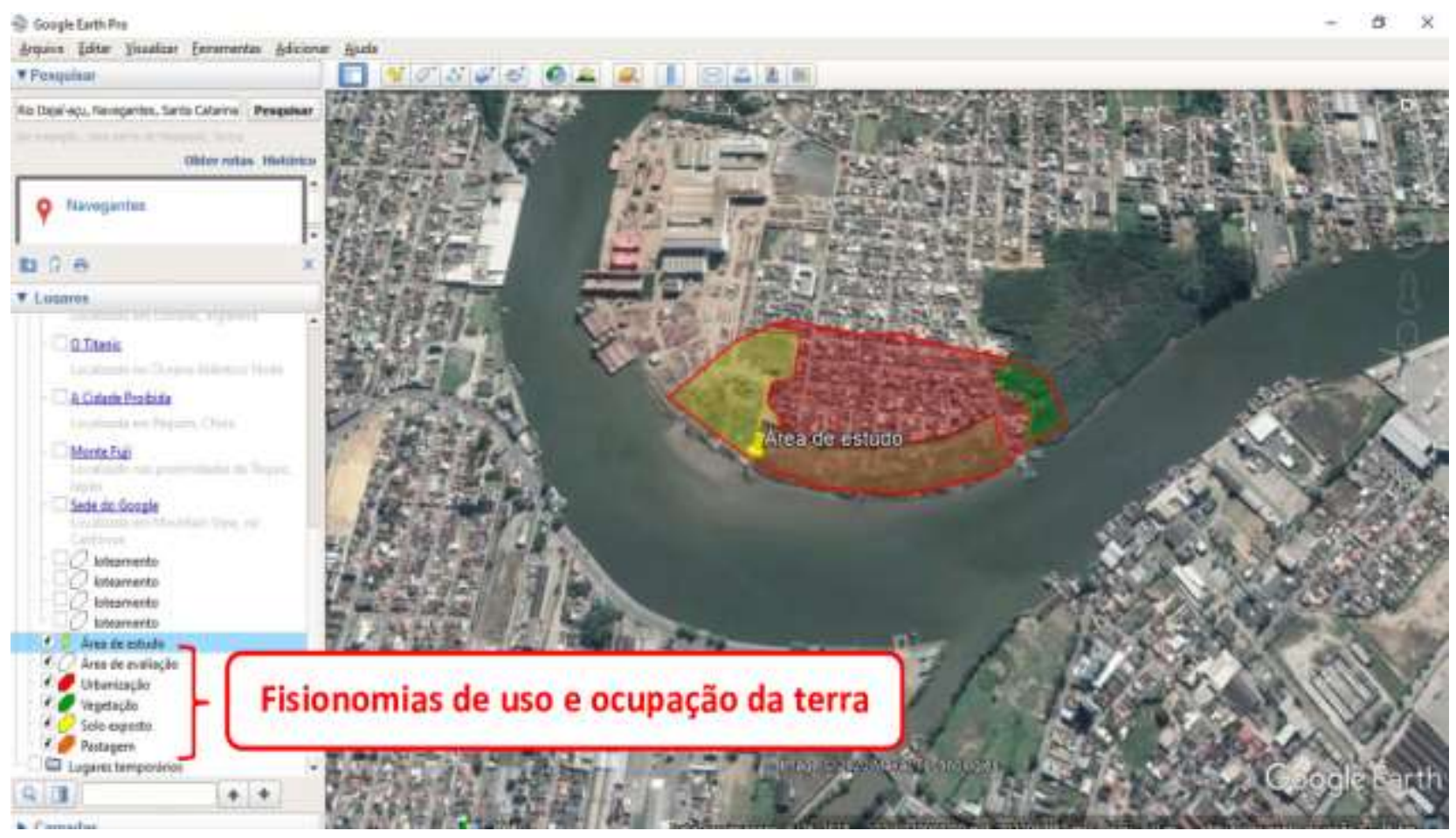

Fonte: Autores (2020)

Para quantificar a área ocupada, você deverá seguir os passos abaixo, conforme demonstrado na figura 15:

- Clique em "pastagem ou solo exposto ou urbanização ou vegetação" (indicado pela caixa em amarelo);

- Com o mouse no botão direito, acione "propriedades";

- Clique na aba medidas e você obterá a área metros quadrados para cada fisionomia; anote o valor da área em um caderno ou uma tabela e clique em "ok".

Sugere-se a construção uma tabela para anotar o valor de cada área de fisionomia quantificada, uma vez que, podemos ter vários polígonos para um mesmo tipo de uso e ocupação da terra (figura 16).

Assim, os dados obtidos no processo estarão organizados e de fácil compreensão para posterior análise. 
Figura 15 - Quantificando o uso e ocupação da terra

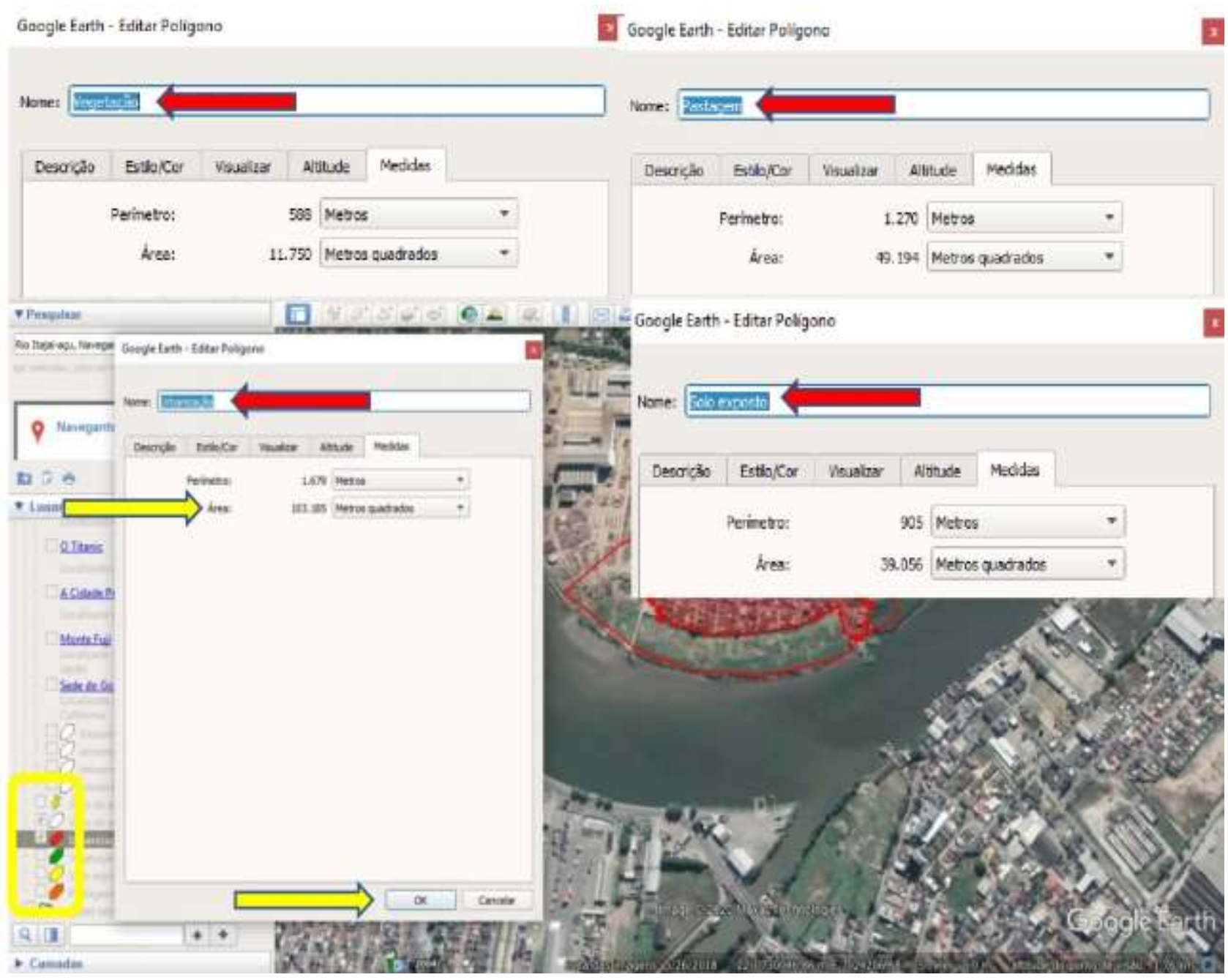

Fonte: Autores (2020)

Figura 16 - Quantificação dos dados.

\begin{tabular}{|l|l|l|l|l|}
\hline $\begin{array}{c}\text { Área Total Buffer } \\
\left(\mathrm{m}^{2}\right)\end{array}$ & $\begin{array}{c}\text { Área Pastagem } \\
\left(\mathrm{m}^{2}\right)\end{array}$ & $\begin{array}{c}\text { Área Solo exposto } \\
\left(\mathrm{m}^{2}\right)\end{array}$ & $\begin{array}{c}\text { Área Urbanizaçāo } \\
\left(\mathrm{m}^{2}\right)\end{array}$ & $\begin{array}{c}\text { Área Vegetaçāo } \\
\left(\mathrm{m}^{2}\right)\end{array}$ \\
\hline & & & & \\
\hline & & & & \\
\hline & & & & \\
\hline Total & & & & \\
\hline
\end{tabular}

Fonte: Autores (2020) 
Finalizando a coleta de dados do território de estudo, a partir da aplicação da geotecnologia, vamos partir para a análise dos resultados!

\subsection{Proposta de Sistematização e avaliação dos resultados}

Com as medições preenchidas figura 16, dados reais, teremos os valores em metros quadrados de cada influência (pastagem, solo exposto, urbanização e vegetação), da área de estudo em questão. A área é heterogênea, ou seja, apresenta um ou mais fragmentos de uma mesma fisionomia. Desta forma, se tivermos vários polígonos de uma mesma fisionomia teremos que somar a sua área total. No exemplo citado no tópico anterior, temos um polígono para cada área, então nossa tabela ficaria da seguinte forma (figura 17): 
Figura 17 - Quantificação dos dados.

\begin{tabular}{|c|c|c|c|c|}
\hline $\begin{array}{c}\text { Area Total Buffer } \\
\left(\mathrm{m}^{2}\right)\end{array}$ & $\begin{array}{c}\text { Area Pastagem } \\
\left(\mathrm{m}^{2}\right)\end{array}$ & $\begin{array}{c}\text { Área Solo exposto } \\
\left(\mathrm{m}^{2}\right)\end{array}$ & $\begin{array}{c}\text { Area Urbanização } \\
\left(\mathrm{m}^{2}\right)\end{array}$ & $\begin{array}{c}\text { Área Vegetaçăo } \\
\left(\mathrm{m}^{2}\right)\end{array}$ \\
\hline 203,185 & 49,194 & 39,056 & 103,185 & 11,750 \\
\hline
\end{tabular}

Fonte: Autores (2020)

Agora para caracterizar as áreas de maior influência ou menor, podemos transformar nossos valores que estão em metros quadrados para um índice de porcentagem. Sabemos que o valor total do buffer corresponde a 100\% da área, a partir dele, conseguiremos calcular os demais índices aplicando matematicamente a regra de três (figura 18). Então, vamos ao cálculo das porcentagens!

Sucessivamente, se aplicarmos a regra de três para as demais fisionomias obteremos as seguintes porcentagens: solo exposto, 19,22 \%; urbanização, 50,78 \% e vegetação, 5,79\%.

Figura 18 - Aplicando a regra de três

\begin{tabular}{|c|c|}
\hline Área total avaliada (buffer) & $100 \%$ \\
\hline Área de cada fisionomia & $\mathbf{x}$ \\
\hline \multicolumn{2}{|c|}{ Cálculo da área de Pastagem } \\
\hline 203,185 & $100 \%$ \\
\hline 49,194 & $\mathbf{x}$ \\
\hline \multicolumn{2}{|c|}{ Agora, multiplicamos os meios pelos extremos, obtendo uma divisão: } \\
\hline \multicolumn{2}{|c|}{$X=4.919,4 / 203,185$} \\
\hline \multicolumn{2}{|c|}{$X=24,21 \%$} \\
\hline $\begin{array}{l}\text { Assim, concluímos que da área } \\
\text { área total avaliada. }\end{array}$ & $1 \%$ da \\
\hline
\end{tabular}

Fonte: Autores (2020) 
A situação atual do ecossistema aquático em questão é fruto de toda uma influência do buffer analisado. Assim, podemos consideram as fisionomias: pastagem como de menor impacto (desmatamento); solo exposto de impacto moderado (desmatamento, agrotóxicos e pesticidas), urbanização de alto impacto (desmatamento, dejetos industriais, esgotos e lixos domésticos), e vegetação (área florestada) como não impactante (MACEDO, 2014). Portanto, dependendo do resultado das porcentagens, você poderá inferir sobre qual o tipo de impacto está atuando no rio ou território que vocês avaliaram.

Considerando o exemplo realizado acima podemos inferir que a área avaliada apresenta $94,21 \%$ de interferência humana, sendo mais de $50 \%$ considera do alto impacto (urbanização) e, poderíamos aplicar o novo código florestal brasileiro para Área de Preservação Permanente (APP), pela Lei No 12. 651 de maio de 2012, pois a área de mata ciliar as margens do rio não estão sendo respeitada. Assim sendo, diagnosticamos que o uso e a ocupação da terra podem estar comprometendo a qualidade da água do rio e consequentemente colocando em risco a saúde da população em seu entorno.

Fica a sugestão para discussão com seus amigos, professores, familiares e representantes legais de seu município sobre a situação do ecossistema aquático escolhido pelo grupo.

Corroborando com a sugestão acima, a Base Nacional Comum Curricular, consta que ciência e tecnologia se desenvolvem de forma integrada e, essa construção resulta em novos ou melhores produtos e serviços que promovem o equilíbrio entre natureza e sociedade. Nesse ensejo entre educação, tecnologia, sociedade e ambiente, garantiremos a manutenção salutar de nossos recursos naturais e a proteção à vida!

\section{CONSIDERAÇÕES FINAIS}

O presente roteiro abordou uma proposta teórico-prática-tecnológica alicerçado no desenvolvimento da aprendizagem proposto pela Base Nacional Comum Curricular (BNCC) e pelos Temas Contemporâneos Transversais (TCTs) nas macro áreas Meio 
Ambiente e Ciência e Tecnologia. Nessa perspectiva de aprendizagem, a mesma foi fundamentada, inferindo o educando ao mundo tecnológico como protagonista da educação, conforme as propostas de Rousseau (1712-1778), aprendizagem voltada para o interesse do educando, Vygotsky (1896-1934), na concepção de um sujeito interativo, Lévy (1993) na intervenção da tecnologia como principal ponto de apoio de um processo ininterrupto de aprendizagem, e de Jonassen (1996), onde a tecnologia aproxima os sujeitos da aprendizagem, através da observação reflexiva, experimentação ativa e na resolução de conflitos concretos do mundo.

A tecnologia provoca novas formas de ver o mundo, de senti-lo e de estar nele. Essas perspectivas incorporadas as práticas pedagógicas educacionais, elucubra para a formação de sujeitos críticos e conscientes de seu lugar no mundo e da sua participação como cidadão em seu contexto social. Não é tratar a tecnologia como algo acabado, e sim como um meio, uma ponte, que conecte o conhecimento a ser apreendido com a realidade vivida. É imprescindível que a escola possa oferecer conhecimento científico tecnológico capaz de formar cidadãos sujeitos da história, construindo assim, a educação científica.

Estimular a elaboração de hipóteses, oferecer instrumentos metodológicos que possam testar estas hipóteses e argumentar resultados, são elementos essenciais na base para a construção científica. Todos estes elementos reforçarão o papel do conhecimento na construção de pessoas críticas, embasadas de conhecimento científico e ativas na sociedade em que estão inseridas.

Dessa forma, unindo o conhecimento de teóricos-educacionais-tecnológicos, documentos norteadores e o planejamento escolar (roteiro), a educação no Brasil se constrói com profissionais aguerridos e eruditas, que formarão indivíduos na sua complexidade biológica, psicológica, cultural e social, ou seja, em sua integralidade. Nesse ensejo, a Educação Ambiental e a Ciência Tecnológica adentra nessa integração, transcendendo para além contexto escolar, transformando o educando antes passivo, em um ser crítico e ativo no meio em que vive, disposto a lutar por problemas sociais e ambientais vigentes, exercendo a cidadania e transformando vidas. 
Diante do exposto, com práticas de ensino planejadas e fundamentadas, voltadas para a Educação Ambiental a partir do uso de Geotecnologias, aplicadas ao ensino na área da Geografia, onde o educando é protagonista da educação, construiremos um ambiente escolar transformador, que supera a dicotomia homem e natureza e desenvolve a sensibilidade para com o meio ambiente e a qualidade de vida das futuras gerações.

\section{REFERÊNCIAS}

ALMEIDA, S. N. de O. Concepções de educação integral e suas relações com equidade educacional. 2018. 246 p. Tese (Doutorado em Educação) - Universidade Federal da Bahia, Salvador, 2018.

AMBIENTE BRASIL. Indicador de impacto ambiental. S.I. 2020. Disponível em: <https://ambientes.ambientebrasil.com.br/agropecuario/artigo_agropecuario/indicadores_de_impa cto_ambiental_no_solo.html $>$. Acesso em 06 abr. 2020.

BRASIL. Código Florestal, Lei n¹2.651, de 25 de maio de 2012. Dispõe sobre a proteção da vegetação nativa. Diário Oficial da União, Brasília, DF, 25 mai. 2012. Disponível em: < http://www.planalto.gov.br/ccivil_03/_ato2011-2014/2012/lei//12651.htm>. Acesso em 22 abr. 2020.

BRASIL. Conselho Nacional do Meio Ambiente - CONAMA. Resolução No 001, de 23 de janeiro de 1986. CONAMA. Dispõe sobre critérios básicos e diretrizes gerais para a avaliação de impacto ambiental. Diário Oficial da União, $D F, \quad$ v. 17, n. 02, 1986. Disponível em: <http://www2.mma.gov.br/port/conama/legislacao/CONAMA_RES_CONS_1986_001.pdf>. Acesso em 20 abr. 2020.

BRASIL. Lei n.9.394, de 20 de dezembro de 1996. Estabelece as Diretrizes e Bases da Educação Nacional. Diário Oficial da República Federativa do Brasil, Poder Executivo, Brasília, DF, 21 dez. 1996. Disponível em: <http://www.planalto.gov.br/ccivil_03/LEIS/L9394.htm>. Acesso em 16 abr. 2020.

BRASIL. Ministério da Educação. Guia de Implementação dos Temas contemporâneos transversais na Base Nacional Comum Curricular: propostas de práticas de implementação. MEC, Brasília, DF, 2018. Disponível em: http://basenacionalcomum.mec.gov.br/images/implementacao/guia_pratico_temas_contemporane os.pdf. Acesso: 11 ago. 2020.

BRASIL. Ministério da Educação. Secretaria de Educação Básica. Base Nacional Comum Curricular Terceira versão. Brasília, DF: MEC/SEB, 2017.Disponível em: <http://basenacionalcomum.mec.gov.br> Acesso em 16 jul. 2020. 
BRASIL. Ministério da Educação. Secretaria de Educação Básica. Diretrizes Curriculares Nacionais Gerais da Educação Básica Diretoria de Currículos e Educação Integral. Brasília: MEC/SEB, DICEI, 2013.

BRASIL. SECRETARIA DE EDUCAÇÃO FUndAMENTAL. Parâmetros Curriculares Nacionais: introdução aos parâmetros curriculares nacionais. 1997.

BRASIL. Lei no 13.005, 25 de junho de 2014. Aprova o Plano Nacional da Educação - PNE. Diário Oficial da União, Poder Legislativo, Brasília, DF. Disponível em: <http://www.planalto.gov.br/ccivil_03/_ato2011-2014/2014/lei/113005.htm>. Acesso em: 05 ago. 2020.

BUENO, S. Minidicionário da Língua portuguesa. São Paulo: FTD, 2007.

CASTRO, J. L. S. et al. Mata ciliar: Importância e funcionamento. In: VIII CONGRESSO BRASILEIRO DE GESTÃO AMBIENTAL, 8., 2017, Campo Grande. Anais XI. Campo Grande: IBEAS, 2017.

FITZ, P. R. Novas tecnologias e os caminhos da Ciência Geográfica. Diálogo Tecnologia. 6. ed., p. 35-48. Canoas: Centro Universitário la Salle, 2005.

FRANÇA, J. S.; CALISTTO, M. Monitoramento participativo de rios urbanos: por estudantescientistas. 1. ed. Belo Horizonte, 2019. Disponível em: < http://labs.icb.ufmg.br/benthos/index_arquivos/pdfs_pagina/2019/Livro_monitoramento/LivroCom pleto.pdf>. Acesso em: 11 nov. 2020.

GAMA, M. L. S. Planejamento Educacional e Formação de Professores: práticas, sentidos e significados. 1 ed. Curitiba: Appris Editora, 2016.

GOOGLE. Google Earth Pro. Download do Google Earth Pro para PC, Mac ou Linux. Disponível em: <https://www.google.com.br/earth/download/gep/agree.html>. Acesso em 02 de abr. 2020.

IBGE. Instituto Brasileiro de Geografia e Estatística - IBGE. Revista e manuais técnicos. Disponível em: $\quad$ https://www.ibge.gov.br/geociencias/metodos-e-outros-documentos-de-referencia/revistae-manuais-tecnicos>. Acesso em: 24 abr. 2020.

JONASSEN, D. O uso das novas tecnologias na educação à distância e a aprendizagem construtivista. In: Em Aberto, Brasília, ano 16, $\mathrm{n}^{\circ}$ 70, abr/jun 1996. p. 70-88. Disponível em: < https://www.nescon.medicina.ufmg.br/biblioteca/imagem/2504.pdf> Acesso em: 24 abr. 2020.

KLAUMANN, A. P. O problema das inundações no Alto Vale do Itajaí: abordagem exploratória inspirada no debate sobre o desenvolvimento territorial rural. Universidade Federal de Santa Catarina - UFSC. $2017 . \quad$ Disponível em: https://repositorio.ufsc.br/bitstream/handle/123456789/184971/Monografia\%20da\%20Ana\%20Pau la\%20Klaumann.pdf? sequence=12isAllowed=y $>$ Acesso em: 11 abr. 2020

LEVY, P. As tecnologias da inteligência: o futuro do pensamento na era da informática. Tradução de Carlos Irineu da Costa. Rio de Janeiro: Editora 34, 1993. 
LEVY, P. A conexão planetária: o mercado, o ciberespaço, a consciência. 1 ed. São Paulo: Editora 34, 2001.

MACEDO, D. R. et al. Uso e ocupação do solo, sorteio de sítios amostrais, reconhecimento em campo e realização de amostragens. Condições Ecológicas em Bacias Hidrográficas de Empreendimentos Hidrelétricos Serie Peixe Vivo, v. 2, p. 47-68, 2014. Disponível em: <https://www.researchgate.net/publication/276921450_Uso_e_ocupacao_do_solo_sorteio_de_sitios _amostrais_reconhecimento_em_campo_e_realizacao_de_amostragens> Acesso em: 15 jul. 2020.

PORTO, M. F. A.; PORTO, R. LA L. Gestão de bacias hidrográficas. Estudos avançados, v. 22, n. 63, p. 43-60, 2008.

ROSA, R. Geotecnologias na geografia aplicada. Revista do Departamento de Geografia, v. 16, p. 81-90, 2005.

SANTOS, L. A. C.; VIEIRA, L. M. F.; MARTINS, P. T. A.; FERREIRA, A. A. Conflitos de Uso e Cobertura do Solo para o Período de 1985 a 2017 na Bacia Hidrográfica do Rio Caldas-GO. Tecnologia, Inovação e Sustentabilidade. Editora Fronteiras: Journal of Social, Technological and Environmental Science, v. $8, \quad$ n. $2, \quad$ p. 189-211, 2019. Disponível em: < http://periodicos.unievangelica.edu.br/index.php/fronteiras/article/view/2660/2542> Acesso em: 18 set. 2020.

SILVA, M. S. da; LEMOS, S. S. de; MORAES, A. B. de. Uso de geotecnologias para delimitação de Áreas de Preservação Permanente e análise das áreas de conflito de uso e ocupação do solo na zona urbana do município de Mãe do Rio-PA. In: Revista Brasileira de Estudos Urbanos e Regionais. Disponível em: http://anpur.org.br/app-urbana-2014/anais/ARQUIVOS/GT3-72-33-20140518141544.pdf Acesso em 22 maio 2020.

SOUZA, F. F de. Bacias Hidrográficas. UFSCar aprender, São Carlos, SP, 2010. Disponível em: <http://www.ufscar.br/aprender/aprender/2010/06/bacias-hidrograficas/>. Acesso em: 26, abr. 2020.

USGS. Sciense for a changing world. Earth Explorer. Disponível em: < https://earthexplorer.usgs.gov/>. Acesso em 16 abr. 2020.

VENZKE, T. S. L. Estudo das matas ciliares da bacia hidrográfica do Pelotas, Pelotas, RS, Brasil. Geografia Ensino \& Pesquisa, v. 22, p. 29, 2018.

VIEIRA, I. Mapeamento da área de preservação permanente na margem norte do rio Itajaí-Açu em área urbana consolidada. Metodologias e Aprendizado, v. 1, p. 26-29, 2019.

VYGOTSKY, L. S. Linguagem, desenvolvimento e aprendizagem. Tradução de Maria da Penha Villalobos. São Paulo: Ed. da USP, 1988.

WENDT, C. E.; DALBOSCO, C. A. Iluminismo pedagógico e educação natural em Jean-Jacques Rousseau. Educação (UFSM), v. 37, n. 2, p. 229-240, 2012. 
WITTER, G. P. Importância das sociedades/associações científicas: desenvolvimento da ciência e formação do profissional-pesquisador. Boletim de Psicologia, v. 57, n. 126, p. 1-14, 2007. 